\title{
Trophic cascades among wolves, elk and aspen on Yellowstone National Park's northern range
}

\author{
William J. Ripplea,*, Eric J. Larsen ${ }^{\mathrm{b}}$, Roy A. Renkin ${ }^{\mathrm{c}}$, Douglas W. Smith ${ }^{\mathrm{c}}$ \\ ${ }^{a}$ Environmental Remote Sensing Applications Laboratory (ERSAL), Department of Forest Resources, Oregon State University, Corvallis, OR 97331, USA \\ ${ }^{\mathrm{b}}$ Department of Geosciences and Environmental Remote Sensing Applications Laboratory (ERSAL), Department of Forest Resources, Oregon State \\ University, Corvallis, OR 97331, USA \\ ${ }^{\mathrm{c}}$ Yellowstone Center for Resources, PO Box 168, Yellowstone National Park, WY 82190, USA
}

Received 1 November 2000; received in revised form 26 February 2001; accepted 9 April 2001

\begin{abstract}
Quaking aspen (Populus tremuloides) biomass has declined in Yellowstone National Park (YNP) in the past century. We installed permanent belt transects (plots) for long-term monitoring of aspen stands both within and outside of established wolf pack territories on YNP's northern range to determine if reintroduced wolves are influencing elk browsing patterns and aspen regeneration through a trophic cascades interaction. Wolves may have an indirect effect on aspen regeneration by altering elk movements, browsing patterns, and foraging behavior (predation risk effects). Elk pellet groups, aspen sucker heights, and the percentage of browsed suckers were the variables used to measure differences in aspen stands in high and low wolf-use areas of the northern range. The aspen stands in the high wolf-use areas had significantly lower counts of elk pellet groups in the mesic upland steppe and the combined mesic upland steppe and riparian/wet meadow habitat types. Based on our pellet group results, it appears that elk foraging behaviors may have been altered by the increased risk of predation due to the reintroduction of the wolf. In the riparian/ wet meadow habitat type, mean aspen sucker heights were significantly higher in the high wolf-use areas than in the low wolf-use areas. The percentage of browsed suckers in high and low wolf-use areas showed no significant differences in any of the habitat types. Considering the high browsing pressure in YNP aspen stands, it is uncertain whether the taller aspen suckers measured in the high wolf-use areas will eventually join the aspen overstory. These permanent plots represent a valuable baseline data set to assess any current and future aspen regeneration responses to the reintroduction of wolves in YNP. C) 2001 Elsevier Science Ltd. All rights reserved.
\end{abstract}

Keywords: Yellowstone National Park; Aspen; Wolf; Elk; Trophic cascades

\section{Introduction}

Quaking aspen is the most widely distributed tree in North America. It is native to Yellowstone National Park's (YNP) northern range, a 100,000-ha area including the valleys of the Yellowstone, Lamar, and Gardiner rivers. It is estimated that aspen historically covered $4-6 \%$ of the northern range (Houston, 1982) but that percentage has declined to approximately $1 \%$ of the landscape (Larsen and Ripple, 1998, unpublished data). The character of aspen stands has also changed from a previous condition of variable age classes to its

* Corresponding author. Tel.: + 1-541-737-3056; fax: + 1-541-7373049 .

E-mail address: bill.ripple@orst.edu (W.J. Ripple). current state of mature/declining stands of older stems (Warren, 1926; Meagher and Houston, 1998). On some northern range sites, aspen clones also exist in a perennial shrub or herb form (Despain, 1990; Renkin and Despain, 1996). Aspen seedling establishment is considered rare but once a root system is established it may persist for centuries (Knight, 1994). Aspen usually occur in clonal stands of genetically identical stems. The individual stems originate as suckers growing from a common root system, so the stems making up a clonal stand are interconnected and can transfer water and solutes among themselves (Jones and DeByle, 1985).

The decline of aspen biomass on the northern range has become a resource issue of great debate. Much research has revolved around identifying the causes of the decline with the relative roles of climate fluctuation, 
mammalian predation on elk, fire suppression, and ungulate (elk) browsing being considered (Kay, 1994, 1998; Romme et al., 1995; YNP, 1997; Meagher and Houston, 1998; Singer et al., 1998).

Herbivory by elk (Cervus elaphus) has been identified as a proximal factor in the decline of aspen in YNP (YNP, 1997). Elk eat the smooth white bark of aspen trunks, resulting in growths of thick corky bark reaching as high as the elk can reach. This practice can stress aspen and allows cankers and fungi to attack mature stems (Romme et al., 1995). Elk also heavily browse new aspen sprouts emerging from the clonal root system, inhibiting stem growth and maintaining some aspen stands in a shrub form. Ungulate browsing has been identified as preventing the recruitment of younger stems into the overstory and inhibiting clonal expansion, but there is uncertainty over why browsing has a different influence now than it has had historically (YNP, 1997). Elk numbers were manipulated by National Park Service removals (until 1968) and reduced to approximately 4000 animals during the 1960s, but aspen increment core data show that reductions in elk herd size have not led to new cohorts of ramets joining YNP's aspen overstory (Romme et al., 1995; Ripple and Larsen, 2000).

Ripple and Larsen (2000) provide evidence that YNP aspen successfully regenerated overstory stems from the middle to late 1700's-1930. After 1930, aspen overstory regeneration in YNP ceased, except in a few sites protected from browsing. Fallen conifers from the 1988 Yellowstone fires are currently providing refugia for aspen stems, a process that may assist limited aspen persistence on the northern range (Ripple and Larsen, 2001).

Wolves were extirpated as a source of elk predation in YNP between 1914-1926, with at least 136 wolves killed in that period (Weaver, 1978). Ripple and Larsen (2000) hypothesized that aspen decline in YNP may be related to the removal of a trophic cascades interaction where wolves modified elk movements, density, and foraging behavior. A trophic cascade has been defined as "the progression of indirect effects by predators across successively lower trophic levels" (Estes et al., 2001). Wolves may influence lower trophic levels both by killing elk and altering their behavior. It was estimated that wolf reintroduction might reduce the elk population in YNP from 5-20\% (Boyce and Gaillard, 1992; Mack and Singer, 1992). Changes in prey behavior due to the presence of predators are referred to as predation risk effects (Schmitz et al., 1997). These behavioral modifications include changes in diet, temporal alterations of feeding patterns, and spatial changes regarding habitat use, patch selection and choices of feeding sites (Lima and Dill, 1990; McLaren and Peterson, 1994). The presence of wolves may have been crucial in maintaining northern range aspen stands both through pre- dation and especially through predation risks affecting elk movement and herbivory patterns. When wolves were present, ungulate antipredator strategies may have included the avoidance of high wolf use areas (Mech, 1977; Roby, 1978; Allen, 1979; Edwards, 1983; Ferguson et al., 1988). Since wolf recolonization in the early 1970s, researchers in Canada's Banff and Jasper National Parks have found higher elk densities in low wolf predation areas (Dekker, 1985; White et al., 1998). In addition, White et al. (1998) reported that a new cohort of aspen has grown into trees 3-5 $\mathrm{m}$ tall since wolves recolonized Jasper National Park, with particularly vigorous regeneration near wolf trails and other areas of heavy wolf use.

Wolves were reintroduced into YNP in 1995 (Bangs and Fritts, 1996). By the end of 1998, 112 wolves lived in 11 packs in the greater Yellowstone ecosystem (Smith et al., 1999). Four packs had established themselves on the northern range. In 1999, we established permanent transects (plots) in aspen stands to test whether reintroduced wolves may be influencing elk use, browse patterns, and aspen response. Our objective was to compare aspen stands in high and low wolf-use areas to determine if there were significant differences between the two areas in the number of elk pellet groups, aspen sucker heights and the percentage of suckers being browsed. No previous research has established any spatial pattern for elk browsing in northern range aspen stands but the uniform lack of overstory recruitment suggests that all aspen stands available to ungulates were heavily browsed. To rectify this situation and monitor possible ecological change over time, we sought to establish baseline data for the three trophic levels involving wolves, elk, and aspen on YNP's northern range.

\section{Methods}

An inventory of YNP northern range aspen stands was created from a set of 1:24,000 color infrared (CIR) aerial photographs taken in October 1988, at the conclusion of the fire season. A grid of 96 rectangular cells $(1 \times 1.5 \mathrm{~cm}, 240 \times 360 \mathrm{~m}$ on the ground) was overlain on each CIR aerial photograph. A scanning stereoscope was used to identify grid cells containing large-stem aspen and a comprehensive list of cells containing aspen was compiled from the photographs to produce the inventory.

We used wolf telemetry data (Smith, 1999, unpublished data) and KernalHR software (Seaman et al., 1996, 1997) to determine high and low wolf-use areas on YNP's northern range. The high-use areas included territories occupied by the Druid, Rose Creek, and Leopold wolf packs. As of 31 December, 1998, the Druid, Rose Creek and Leopold packs contained 7, 22, and 13 animals, respectively (Smith et al., 1999). The telemetry 
data consisted of a pack designator and the UTM coordinates for the observations. The telemetry data were collected from November through April in 1996/ 1997 and 1997/1998 and consisted of 180 observations for the Leopold wolf pack, 272 for the Rose Creek pack, and 296 for the Druid pack.

We combined the aspen inventory with the wolf telemetry data to select our sample. The software program KernelHR was used to develop a fixed kernel estimate of high-use areas for wolves in the three packs (Seaman et al., 1997). The kernel method is a statistical technique for estimating the density of a distribution (presence of wolves) at any point, where a kernel (a probability density) is placed over each observation point in a sample (Silverman, 1986; Seaman and Powell, 1996). An estimate of the density is then calculated based on the average of the densities that overlap that point, providing an estimate of wolf use in that location over time. Using these estimates, we developed contours delineating polygons that represented the density of winter season use for the three wolf packs. To compensate for spatial autocorrelation we created a buffer between the fixed kernel estimates we used to define our low and high wolf-use areas. We then overlaid these polygons onto our aspen inventory and grouped aspen stands into areas of high use by wolves (inside the $50 \%$ fixed kernel estimate) and low use (outside of the $75 \%$ fixed kernel estimate). We then randomly chose 59 of the $240 \times 360 \mathrm{~m}$ cells containing aspen that were located within the $50 \%$ fixed kernel estimates for the three packs; 16 within the Leopold pack area, 21 in the Rose Creek pack territory, and 22 in the Druid pack territory.

In the low wolf-use area of the elk winter range in YNP, a total of 53 of the grid cells containing aspen were randomly selected for study. Recognizing the dynamic nature of wolf pack boundaries and the possibility of increased activity in different areas as packs expand or splinter, we selected a subset of 17 of our low wolf-use study sites to be within $1.5 \mathrm{~km}$ of developed areas near Mammoth Hot Springs, the Youth Conservation Corps complex, and Camp Roosevelt. These sites make good long-term study sites since wolves avoid areas of significant human presence (White et al., 1998). Elk, however, are commonly encountered in these three areas.

We conducted our field research in August and September of 1999, to minimize any possible disturbance of wolf denning sites. We made measurements on all aspen suckers and trees within the plots. Aspen suckers were defined as stems $<2 \mathrm{~m}$ in height, while aspen trees included all stems $>2 \mathrm{~m}$ in height. Based on field measurements, a stand was defined as a group of aspen trees each within $30 \mathrm{~m}$ of one of its cohorts. Each $240 \times 360 \mathrm{~m}$ grid cell could therefore possibly contain several aspen stands if trees were separated by gaps of more than 30 $\mathrm{m}$. If more than one stand occurred in a grid cell, the stands were numbered and a random selection of a single stand was made. We then chose a random cardinal direction for a starting point and established a $1 \times 20 \mathrm{~m}$ plot beginning with the aspen tree $[>10 \mathrm{~cm}$ diameter at breast height $(\mathrm{DBH})]$ standing furthest in the chosen direction. From the starting point, the plot ran into the stand towards its centroid. A metal tag was attached to the aspen tree we started from and the transect line was marked with nine-inch nails placed in the ground at distances of $3,5,10$, and $20 \mathrm{~m}$. We counted the occurrence of elk pellet groups in each plot and included any pellet groups on the edge of the plot line. We counted and measured the height of every aspen sucker in the plot, and determined whether it had been browsed the previous winter. We counted and measured the DBH of all aspen trees and conifer trees in each plot. We determined the Universal Transverse Mercator (UTM) coordinates of each plot using differentially corrected Global Positioning System (GPS) readings. Elevation, topographic aspect, and an aspen habitat type were also recorded.

Three generalized habitat types were developed to control for differences in aspen growth due to site quality (Despain, 1990). The habitat types were delineated in the field based on understory vegetation and site wetness as follows:

1. Xeric upland steppe. The understory of these aspen stands included grasses such as Idaho fescue (Festuca idahoenis), bluebunch wheatgrass (Agropyron spicatum), bearded wheatgrass (Agropyron caninum), and the forb yarrow (Achillea millefolium). These stands were often surrounded by the big sagebrush (Artemisia tridentata)/Idaho fescue habitat type. The soils of these areas were derived from andesite and sedimentary tills and were generally dry.

2. Mesic upland steppe. A mixture of grasses and taller forbs characterizes this habitat type. Timothy (Phleum pratense) was a dominant grass type in the understory of these stands, with Idaho fescue and bearded wheatgrass also occurring. Forbs include yarrow and goldenrod (Solidago missouriensis). The soils of these areas were generally moist and derived from andesite.

3. Riparian/wet meadow. Various types of sedges (Carex sp.) commonly occur on these sites, mixed with timothy and forbs. Soils were wet to saturated in this habitat type.

A fourth group (all mesic types) consisted of the summed observations of the mesic upland steppe and the riparian/wet meadow habitat types. This group was used to summarize the aspen data for moist to wet site conditions.

We hypothesized that the high wolf-use areas would have a lower number of elk pellet groups, higher sucker 
heights, and a lower percentage of browsed suckers when compared to the low wolf-use areas. We grouped our data by habitat types and used the Students $t$-test to compare low and high wolf-use areas for significant differences in the elk pellet groups, mean sucker heights, and the percentage of browsed suckers. We used the Mann-Whitney test when the data was either skewed or kurtotic. We also compared elevations and sucker densities between the low and high wolf-use areas, using the same statistical methods as described above.

\section{Results}

Using the telemetry data, the Kernel HR software and a geographic information system (GIS), high wolf-use areas were defined as those areas inside the $50 \%$ fixed kernel estimates for the Druid, Rose Creek, and Leopold wolf packs (Fig. 1). The Druid pack high-use territory $(<50 \%$ fixed kernel estimate) consisted of 4337 ha in the Lamar River basin approximately centered at the Soda Butte Creek confluence. The Leopold pack had a high-use territory of 3390 ha on YNP's Blacktail Plateau. The Rose Creek pack had a more fragmented high-use territory of 3827 ha in the Lamar and Yellowstone River basins. The number of telemetry locations within each of the wolf-use categories is given in Table 1.
The elevation, topographic aspect, sucker density, and recent fire history of low and high wolf-use area sites were analyzed as possible confounding factors. The mean elevation for the low wolf-use plots was $2089 \mathrm{~m}$ $($ S.D. $=121)$ and for the high wolf-use plots it was 2090 m (S.D. =99). Using the Students $t$-test, we did not find a significant difference in the mean elevations between the high and low wolf-use plots $(P=0.974)$. The proportion of topographic aspects in high and low wolf-use areas respectively were; north 30.4 versus $25.5 \%$, east 19.6 versus $23.5 \%$, south 28.6 versus $27.5 \%$, west 9.0 versus $11.8 \%$, flat 12.5 versus $11.8 \%$. Mean sucker densities were highly variable, ranging from $0-45,500 /$ ha in our study sites. In the low wolf-use area sites, the mean sucker density was $10,132 /$ ha $($ S.D. $=10,232)$ and in the high wolf-use sites it was $10,590 /$ ha (S.D. $=$ 10,550). Using the Mann-Whitney test, no significant difference was found in sucker densities between our high and low wolf-use sites $(P=0.889)$.

Twenty-three stands in our sample $(21 \%)$ contained charred aspen trunks or other evidence of partial burning, probably from the 1988 fire season. The MannWhitney test was used to compare sucker heights and densities between burned and unburned aspen stands. Eleven years after these fires, we found no significant difference between the sucker heights $(P=0.498)$ or densities $(P=0.849)$ when comparing burned and unburned stands. The mean sucker height in the burned

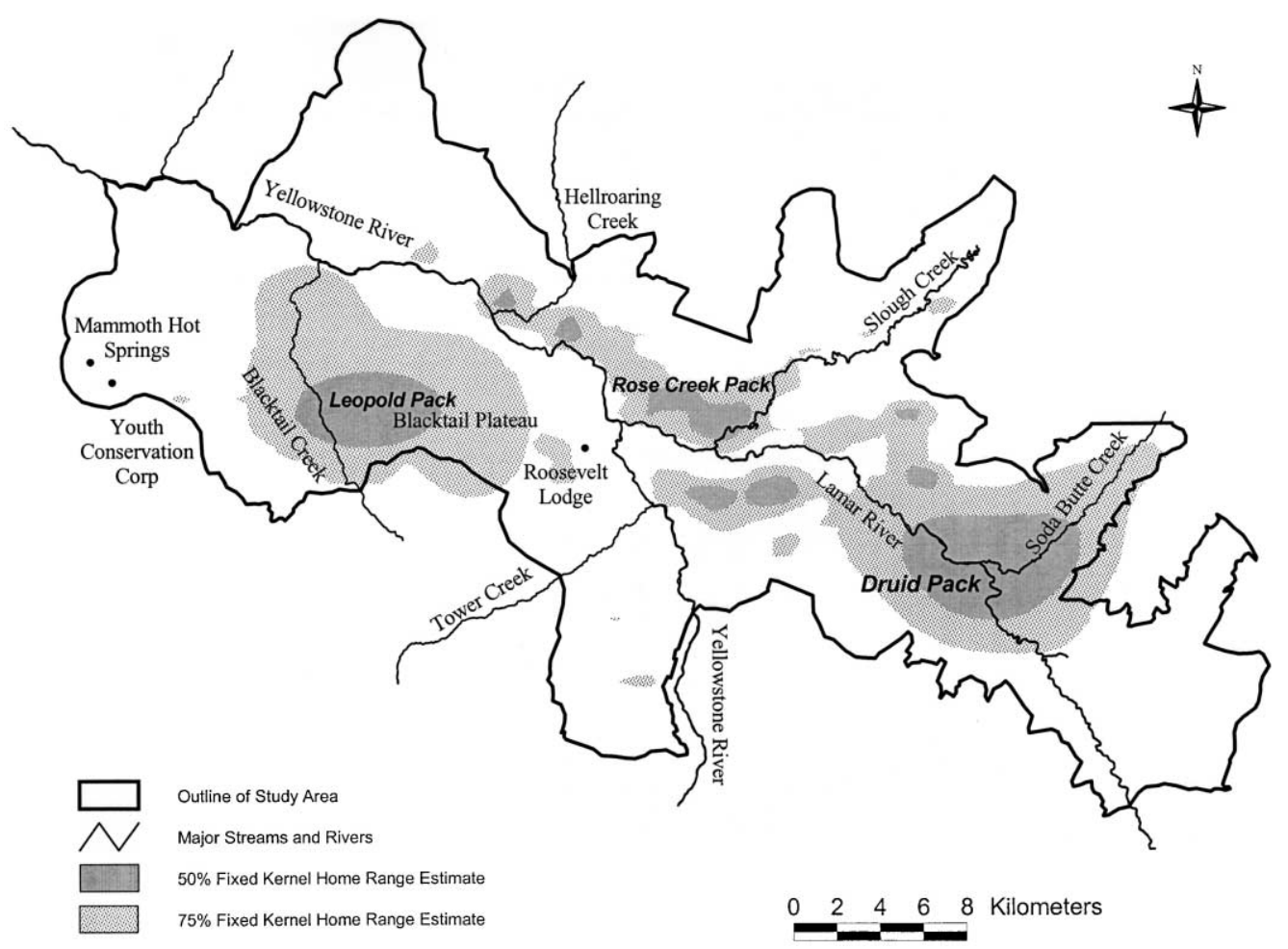

Fig. 1. Study area map showing the 50 and $75 \%$ fixed kernel estimates for the home ranges of the Druid, Rose Creek, and Leopold wolf packs on Yellowstone's northern range. 
Table 1

A comparison of the number of wolf telemetry locations lying within the fixed kernel polygons representing the density of wolf use on YNP's northern range ${ }^{\mathrm{a}}$

\begin{tabular}{lllll}
\hline Wolf pack & $n$ & $\begin{array}{l}\text { Number of } \\
\text { telemetry points in } \\
<50 \% \text { fixed kernel }\end{array}$ & $\begin{array}{l}\text { Number of } \\
\text { telemetry points in } \\
50-75 \% \text { fixed kernel }\end{array}$ & $\begin{array}{l}\text { Number of } \\
\text { telemetry points in } \\
>75 \% \text { fixed kernel }\end{array}$ \\
\hline Rose Creek & 272 & 143 & 78 & 51 \\
Leopold & 180 & 111 & 32 & 37 \\
Druid & 296 & 174 & 101 & 21 \\
\hline
\end{tabular}

a The telemetry points were collected from November-April in 1996-1997. High wolf-use areas were considered to be within the 50\% fixed kernel, while low wolf-use areas were outside the $75 \%$ fixed kernel.

stands was $45.52 \mathrm{~cm}($ S.D. $=14.04)$ and in unburned stands it was $44.19 \mathrm{~cm}($ S.D. $=17.19)$. The mean sucker density in the burned stands was 9065 suckers/ha $($ S.D. $=6587)$ and in unburned stands it was 10,792 $($ S.D. $=11,229)$.

A significant difference in the number of pellet groups was found for the mesic upland steppe $(P=0.002)$ habitat type (Table 2). The low wolf-use areas also had more than twice as many elk pellet groups per plot as the high wolf-use areas when the two wet habitat types were combined $(P=0.002)$. In the xeric upland steppe habitat type we found no significant difference in the number of elk pellet groups between the low and high wolf-use areas.

Aspen sucker heights in the high wolf-use areas were found to be significantly taller in the riparian/wet meadow habitat type than in the low wolf-use area $(P=0.019$, Table 2). In the xeric and mesic upland steppe habitat types, no significant differences were observed between high and low wolf-use areas.

Table 2

A comparison of the number of elk pellet groups, mean aspen sucker heights, and percentage of browsed suckers found in aspen stands in high and low wolf-use areas

\begin{tabular}{|c|c|c|c|c|c|c|c|c|c|c|c|}
\hline \multirow[t]{2}{*}{ Habitat type } & \multicolumn{5}{|c|}{ Low wolf-use areas } & \multicolumn{6}{|c|}{ High wolf-use areas } \\
\hline & $n$ & $\begin{array}{l}\text { Mean no. } \\
\text { of pellet } \\
\text { groups }\end{array}$ & S.D. & Min. & Max. & $n$ & $\begin{array}{l}\text { Mean no. } \\
\text { of pellet } \\
\text { groups }\end{array}$ & S.D. & Min. & Max & $P$-value \\
\hline \multicolumn{12}{|l|}{ Elk pellet groups ${ }^{\mathrm{a}}$} \\
\hline Xeric upland steppe & 12 & 7.1 & 7.6 & 0 & 26 & 11 & 8.6 & 5.4 & 3 & 20 & 0.853 \\
\hline Mesic upland steppe & 25 & 9.2 & 8.0 & 0 & 25 & 21 & 3.2 & 3.2 & 0 & 13 & 0.002 \\
\hline Riparian/wet meadow & 16 & 8.0 & 7.2 & 0 & 23 & 27 & 4.8 & 4.4 & 0 & 17 & 0.088 \\
\hline \multirow[t]{2}{*}{ All mesic types } & 41 & 8.7 & 7.7 & 0 & 25 & 48 & 4.1 & 3.9 & 0 & 17 & 0.002 \\
\hline & $n$ & $\begin{array}{l}\text { Mean } \\
\text { height } \\
(\mathrm{cm})\end{array}$ & S.D. & Min. & Max. & $n$ & $\begin{array}{l}\text { Mean } \\
\text { height } \\
(\mathrm{cm})\end{array}$ & S.D. & Min. & Max & $P$-value \\
\hline \multicolumn{12}{|c|}{ Mean aspen sucker heights $(\mathrm{cm})^{\mathrm{b}}$} \\
\hline Xeric upland steppe & 11 & 40.1 & 15.0 & 14.1 & 64.6 & 10 & 36.1 & 6.2 & 27.4 & 44.4 & 0.568 \\
\hline Mesic upland steppe & 25 & 45.9 & 12.7 & 26.8 & 77.4 & 20 & 48.3 & 19.4 & 27.5 & 110.9 & 0.725 \\
\hline Riparian/wet meadow & 15 & 37.2 & 17.3 & 13.0 & 75.4 & 26 & 49.3 & 18.5 & 26.1 & 93.1 & 0.019 \\
\hline \multirow[t]{2}{*}{ All mesic types } & 40 & 42.6 & 15.0 & 13.0 & 77.4 & 46 & 48.9 & 18.7 & 26.0 & 110.9 & 0.120 \\
\hline & $n$ & Mean & S.D. & Min. & Max. & $n$ & Mean & S.D. & Min. & $\operatorname{Max}$ & $P$-value \\
\hline \multicolumn{12}{|c|}{ Percentage of browsed suckers ${ }^{\mathrm{c}}$} \\
\hline Xeric upland steppe & 12 & $50 \%$ & $36 \%$ & 0 & $100 \%$ & 10 & $57 \%$ & $27 \%$ & $29 \%$ & $80 \%$ & 0.703 \\
\hline Mesic upland steppe & 26 & $57 \%$ & $31 \%$ & 0 & $100 \%$ & 21 & $51 \%$ & $26 \%$ & 0 & $100 \%$ & 0.249 \\
\hline Riparian/wet meadow & 16 & $55 \%$ & $25 \%$ & 0 & $100 \%$ & 27 & $55 \%$ & $28 \%$ & 0 & $100 \%$ & 0.512 \\
\hline All mesic types & 42 & $56 \%$ & $28 \%$ & 0 & $100 \%$ & 48 & $54 \%$ & $27 \%$ & 0 & $100 \%$ & 0.319 \\
\hline
\end{tabular}

a The data is grouped by habitat types with the "All mesic types" class being a combination of the "Mesic upland steppe" and "Riparian wet meadow" classes. The high wolf-use areas are considered to be within the $50 \%$ fixed kernel estimate, while the low wolf-use areas were outside the $75 \%$ fixed kernel estimate. $P$-values based on one-sided Mann-Whitney test (low wolf-use areas $>$ high wolf use areas).

b A comparison of the mean aspen sucker heights $(\mathrm{cm})$ found in aspen stands in high and low wolf-use areas on YNP's northern range. $P$-values based on a one-sided Mann-Whitney test (low wolf-use areas $<$ high wolf-use areas).

c A comparison of the percentage of browsed suckers in aspen stands in low and high wolf-use areas on YNP's northern range. $P$-values based on a one-sided Student's $t$-test (low wolf-use areas $>$ high wolf-use areas). 
We found that there was not a significant difference in the percentage of suckers browsed between the low and high wolf-use areas in any of the habitat types (Table 2). The percentages of browsed suckers in the three habitat types varied from $50-57 \%$ in the low wolf-use areas and from $51-57 \%$ in the high wolf-use areas.

\section{Discussion}

There is mounting evidence that predators such as the gray wolf may influence their communities in a cascade of interactions extending through several trophic levels (Estes, 1996; Schmitz, 1997; Kie, 1999; Pace et al., 1999; Terborgh et al., 1999; Estes et al., 2001). Since wolves were reintroduced to YNP in 1995, elk have been their preferred prey and annually comprise $>80 \%$ of observed kills (Phillips and Smith, 1997; Smith, 1998; Smith et al., 1999). In addition to the killing of elk, wolf predation may also cause modifications in elk behavior that may benefit northern range aspen. This hypothesis is based on the theory of predation risk where the presence of a predator may cause prey to alter their foraging behavior (Lima and Dill, 1990; Schmitz et al., 1997). Predation risk represents a trade-off in foraging strategy in which elk may avoid certain high quality habitats (aspen stands) in order to reduce their risk of predation by wolves. Dekker (1997) suggested that elk prefer to remain in open country so that they can see predators from afar, and considered this behavioral preference an anti-predator strategy.

To understand the full impact of predators on plant and animal communities it may be necessary to look beyond the direct killing of prey and also consider the effects of predation in altering prey behaviors. This may help explain why the elk herd reduction programs conducted in YNP from 1923-1968 did not result in the regeneration of tree-sized aspen. Aspen suckers were not able to escape browsing and grow to tree height during this period, despite the herd reductions (Barmore, 1965; Romme et al., 1995; Huff and Varley, 1999; Ripple and Larsen, 2000). In the absence of predation, elk may have been employing an energy-maximizing foraging strategy rather than a time-minimizing predation risk strategy. Since aspen is a small component of the northern range landscape and is highly palatable to elk (Nelson and Leege, 1982; White et al., 1998), even low population levels of elk could theoretically suppress aspen regeneration through an energy-maximizing optimal foraging strategy (Stephens and Krebs, 1986; Kie, 1999).

In the mesic upland steppe and combined mesic habitat types we found a significantly lower number of elk pellet groups in the high wolf-use areas. This result is consistent with elk using a predation risk foraging strategy and avoiding aspen stands in high wolf-use areas. Repeat comparisons of elk pellet counts in low and high wolf-use areas over time will help establish the significance of this finding. It should also be noted that elk pellets are difficult to count in the tall grass/forb understory of the mesic and riparian aspen stands and our figures represent a minimum number of pellet groups. However, the same two observers counted pellets in both areas so the error should be consistent between high and low wolf-use areas. In addition, deposition of elk pellets may not always occur at foraging sites.

In the xeric upland steppe, we found no differences in the number of elk pellet groups between low and high wolf-use areas. This lack of difference may be due to the relatively long persistence of pellets on xeric sites (Harestad and Bunnell, 1987). Pellets on dry sites with sparse vegetation often persist for many years in a relatively unchanged condition (Van Etten and Bennet, 1965). Some of the pellet groups on our xeric sites may have been deposited before or soon after the wolf reintroduction of 1995, confounding our results.

In the riparian/wet meadow habitat type, we observed that aspen stands in the high wolf-use areas had greater mean sucker heights. This supports our hypothesis, but other explanations regarding aspen growth and elk browsing patterns need to be considered. An important factor in the spatial pattern of northern range browsing is the severity of the winter weather (Houston, 1982). A high water equivalent or hard crust on the snow makes it more difficult for elk to penetrate the snow pack. Snow depth is positively correlated with elevation and deep snow forces elk to lower elevations where forage is more readily available. However, we do not believe elevation, snow depth, or the water equivalent of the snow pack can adequately explain the trends we observed, since we found no significant difference in elevations between the low and high wolf-use plots. Further research is needed to determine how elk respond to both variations in winter weather and the water equivalency in the snowpack.

Furthermore, we found a lack of consistency in some of the results. For example, significantly more elk pellet groups were found in the low wolf-use areas of the upland mesic habitat type than in the high wolf-use areas, yet no difference was found in aspen sucker heights between the low and high wolf-use areas in the same habitat type. Since our data were collected only 4 years after wolf reintroduction it is logical that we saw more of a difference in elk pellet groups (second trophic level) than aspen sucker heights (first trophic level) with the current high browsing pressure. It is unclear why we saw similar percentages of suckers browsed between the low and high wolf-use areas and among the three habitat types. The percentage of browsed suckers may not be a sensitive variable for detecting early signs of trophic cascades with high elk browsing pressure.

The greater mean sucker heights in the riparian/wet meadow habitat type may be an initial response to the 
presence of wolves and evidence of a predation risk effect on elk. However, detailed observations of wolves causing changes in elk foraging behavior do not exist for YNP at this time. Repeated measurements in our permanent transects will determine whether the differences in sucker heights between the low and high wolfuse areas is significant or simply reflects the site variation in current annual growth that could be negated by winter ungulate browsing.

The lower density of elk pellets and the greater mean sucker heights in the mesic habitats suggest that elk may be avoiding these areas where wolves are present, resulting in greater sucker growth even though total browsing pressure is still high. If this pattern continues, the higher growth rates associated with productive riparian/wet meadow aspen stands in the high wolf-use areas would be the first places where recruitment of treesized aspen may occur in the future. Conversely, since the overall browsing pressure on YNP aspen stands is high, we are uncertain whether the differences we measured in sucker heights will eventually translate into renewed recruitment of tree-sized aspen. Long-term sampling of our plots will help clarify the spatial patterns of aspen growth associated with a possible trophic cascades effect involving wolves, elk, and aspen. The empirical patterns are equivocal for more xeric sites and therefore the implications are also unclear, so continued monitoring and sampling are also needed on these plots.

This is the first study in YNP to attempt to measure aspen regeneration success due to predation risk induced effects in elk foraging behavior. Studying how the influence of a top predator can ripple through these three trophic levels will provide baseline ecological data and enhance decision-making regarding park resources. Finally, this research will further our understanding of the role of wolves, elk, and aspen in YNP, thereby obtaining a more comprehensive understanding of this unique and often contentious natural system.

\section{Acknowledgements}

The authors thank William H. Romme for reviewing an early draft of this manuscript. Mark L. Hanus provided advice on forest mensuration topics. Thanks to Christie Hendrix for assistance in the field. The YNP Center for Resources provided assistance in housing and computer use. Kobe Harkins, Elizabeth M. Glenn, and Andrea S. Laliberte provided GIS assistance. The permanent plot data is archived at the Yellowstone Center for Resources.

\section{References}

Allen, D.L., 1979. Wolves of Minong. Houghton Mifflin Company, Boston.
Bangs, E.E., Fritts, S.H., 1996. Reintroducing the grey wolf to central Idaho and Yellowstone National Park. Wildlife Society Bulletin 24, 402-413.

Barmore, W.J., 1965. Aspen-elk relationships of the northern Yellowstone winter range. Paper Presented at the Western Ass. of Fish and Game Commissions, Elk Workshop, Bozeman, MT, March 2-4.

Boyce, M.S., Gaillard, J.M., 1992. Wolves in Yellowstone, Jackson Hole, and the North Fork of the Shoshone River: simulating ungulate consequences of wolf recovery. In: Varley, J.D., Brewster, W.G. (Eds.), Wolves for Yellowstone? A Report to the United States Congress, Vol. IV. Research and Analysis. National Park Service, Yellowstone National Park, pp. 4-116.

Dekker, D.G., 1985. Elk population fluctuations and their probable causes in the Snake Indian Valley of Jasper national park: 19701985. Alberta Naturalist 15, 49-54.

Dekker, D.G., 1997. Wolves of the Rocky Mountains from Jasper to Yellowstone. Hancock House, Blaine, WA.

Despain, D.G., 1990. Yellowstone Vegetation. Consequences of Environment and History in a Natural Setting. Roberts Rinehart, Boulder, Co. USA.

Edwards, J., 1983. Diet shifts in moose due to predator avoidance. Oecologia 60, 185-189.

Estes, J.A., 1996. Predators and ecosystem management. Wildl. Soc. Bull. 24, 390-396.

Estes, J.A., Crooks, K., Holt, R., 2001 Predators, ecological role of. In Levin, S.A. (Ed.), Encyclopedia of Biodiversity. Academic Press, Vol. 4, pp. 857-878.

Ferguson, J.W., Bergerud, A.T., Ferguson, R., 1988. Predation risk and habitat selection in the persistence of a remnant caribou population. Oecologia 76, 236-245.

Harestad, A.S., Bunnell, F.L., 1987. Persistence of black-tailed deer fecal pellets in coastal habitats. Journal of Wildlife Management 51, 33-37.

Houston, D.B., 1982. The Northern Yellowstone Elk. Ecology and Management. Macmillan Publishing Co.

Huff, D.E., Varley, J.D., 1999. Natural regulation in Yellowstone National Park's northern range. Ecological Applications 9, 17-29.

Jones, J.R., DeByle, N.V., 1985. Fire. In: DeByle, N.V., Winokur, R.P. (Eds.), Aspen: Ecology and Management in the Western United States (US Forest Service General Technical Report RM 119). Fort Collins, Co., pp. 77-81.

Kay, C.E., 1994. Aboriginal overkill. The role of Native Americans in structuring western ecosystems. Human Nature 5, 359-396.

Kay, C.E., 1998. Are ecosystems structured from the top-down or bottom-up: a new look at an old debate. Wildlife Society Bulletin 26, 484-498.

Kie, J.G., 1999. Optimal foraging and risk of predation: effects on behavior and social structure in ungulates. Journal of Mammology 80, 1114-1129.

Knight, D.H., 1994. Mountains and Plains: The Ecology of Wyoming Landscapes. Yale University Press, USA.

Larsen, E.J., Ripple, W.J., 1998. Unpublished data. Department of Forest Resources. Oregon State University, Corvallis, OR.

Lima, S.L., Dill, L.M., 1990. Behavioral decisions made under the risk of predation: a review and prospectus. Canadian Journal of Zoology $68,619-640$.

Mack, J.A., Singer, F.J., 1992. Predicted effects of wolf predation on northern range elk, mule deer, and moose using POP-II models. In: Varley, J.D., Brewster, W.G. (Eds.), Wolves for Yellowstone? A Report to the United States Congress, Vol. IV. Research and Analysis. National Park Service, Yellowstone National Park, pp. 4-70.

McLaren, B.E., Peterson, R.O., 1994. Wolves, moose, and tree rings on Isle Royale. Science 266, 1555-1558.

Meagher, M.M., Houston, D.B., 1998. Yellowstone and the Biology of Time. University of Oklahoma Press, Norman, Oklahoma.

Mech, L.D., 1977. Wolf-pack buffer zones as prey reservoirs. Science 198, 320-321. 
Nelson, J.R., Leege, T.A., 1982. Nutritional requirements and food habits. In: Thomas, J.W., Toweill, D.E. (Eds.), Elk of North America: Ecology and Management. Stackpole Books, Harrisburg, PA, pp. 323-367.

Pace, M.L., Cole, J.J., Carpenter, S.R., Kitchell, J.F., 1999. Trophic cascades revealed in diverse ecosystems. Trends in Ecology and Evolution 14, 483-488.

Phillips, M.K., Smith, D.W., 1997. Yellowstone Wolf Project Biennial Report 1995 and 1996. Yellowstone Center for Resources, Yellowstone National Park, WY.

Renkin, R., Despain, D., 1996. Preburn root biomass/basal area influences on the response of aspen to fire and herbivory. In: Greenlee, J.M. (Ed.), Ecological Implications of Fire in Greater Yellowstone. International Association of Wildland Fire, Fairfield, WA, pp. 95-103.

Ripple, W.J., Larsen, E.J., 2000. Historic aspen recruitment, elk, and wolves in Northern Yellowstone National Park, USA. Biological Conservation 95, 361-370.

Ripple, W.J., Larsen, E.J., 2001. The role of postfire coarse woody debris in aspen regeneration. Western Journal of Applied Forestry 16 (2), 61-64.

Roby, D.D., 1978. Behavioral patterns of barren-ground caribou of the Central Arctic herd adjacent to the Trans-Alaska Pipeline. MS thesis, University of Alaska, Fairbanks.

Romme, W.H., Turner, M.G., Wallace, L.L., Walker, J.S., 1995. Aspen, elk, and fire on the northern range of Yellowstone National Park. Ecology 76, 2097-2106.

Schmitz, O.J., Beckerman, A.P., O’Brien, K.M., 1997. Behaviorally mediated trophic cascades: effects of predation risk on food web interactions. Ecology 78, 1388-1399.

Seaman, D.E., Griffith, B., Powell, R.A., 1997. KernelHR: a program for estimating animal home ranges. USGS Biological Resources Division, Forest and Rangeland Ecosystem Science Center, Olympic Field Office, Alaska Coop. Fish and Wildlife Research Unit.

Seaman, D.E., Powell, R.A., 1996. An evaluation of the accuracy of kernel density estimators for home range analysis. Ecology 77, 2075-2085.
Silverman, B.W., 1986. Density Estimation for Statistics and Data Analysis. Chapman and Hall, London, United Kingdom.

Singer, F.J., Swift, D.M., Coughenour, M.B., Varley, J.D., 1998. Thunder on the Yellowstone revisited: an assessment of management of native ungulates by natural regulation, 1968-1993. Wildlife Society Bulletin 26, 375-390.

Smith, D.W., 1999. Unpublished data. Yellowstone Center for Resources, YNP, WY.

Smith, D.W., Murphy, K.M., Guernsey, D.S., 1999. Yellowstone Wolf Project: (Annual Report, 1998). National Park Service, Yellowstone Center for Resources, Yellowstone National Park, WY.

Smith D.W., 1998. Yellowstone Wolf Project: (Annual Report, 1997). National Park Service, Yellowstone Center for Resources, Yellowstone National Park, WY.

Stephens, D.W., Krebs, J.R., 1986. Foraging Theory. Princeton University Press, Princeton, New Jersey.

Terborgh, J., Estes, J.A., Paquet, P., Ralls, K., Boyd-Heger, D., Miller, D.B., Noss, R., 1999. The role of top carnivores in regulating terrestrial ecosystems. In: Terborgh, J., Soule, M. (Eds.), Continental Conservation: Scientific Foundations of Regional Reserve Networks. Island Press, pp. 39-64.

Van Etten, R.C., Bennet, C.L., 1965. Some sources of error in using pellet-group counts for censusing deer. Journal of Wildlife Management 29, 723-729.

Warren, E.R., 1926. A study of beaver in the Yancey region of Yellowstone National Park. Roosevelt Wildl. Ann. 1, 1-191.

Weaver, J., 1978. The Wolves of Yellowstone (Natural Resources Report No. 14). US Dept of Interior, National Park Service.

White, C.A., Olmsted, C.E., Kay, C.E., 1998. Aspen, elk, and fire in the Rocky Mountain national parks of North America. Wildlife Society Bulletin 26, 449-462.

Yellowstone National Park, 1997. Yellowstone's Northern Range: Complexity and Change in a Wildland Ecosystem. Yellowstone National Park, Mammoth Hot Springs, Wyoming. 